\title{
The Effects of Peer-Video Recording on Students' Speaking Performance
}

\author{
Pham Vu Phi Ho ${ }^{1} \&$ Nguyen Thi Thanh Hong ${ }^{2}$ \\ ${ }^{1}$ Ba Ria - Vung Tau University, Vung Tau City, Vietnam \\ ${ }^{2}$ HCMC University of Social Sciences and Humanities, Ho Chi Minh City, Vietnam \\ Correspondence: Pham Vu Phi Ho, Ba Ria - Vung Tau University, Vung Tau City, Vietnam. E-mail: \\ phamvuphiho@gmail.com
}

Received: March 28, 2019 Accepted: May 16, 2019 Online Published: July 3, 2019

doi:10.5539/ijel.v9n4p178 URL: https://doi.org/10.5539/ijel.v9n4p178

\begin{abstract}
The purpose of the current study is to investigate whether peer video recording helps non-English majored college students enhance their speaking performance. Eighty students were selected and assigned to two groups: an experimental group and a control group. Peer video recording was presented to experimental students while no training was given to students in the control group in the same task-based approach. The data, collected based on a pre-posttest design, were analyzed to find out whether or not there were differences between two groups in terms of fluency, grammar, vocabulary, pronunciation and interactive communication. A questionnaire-based survey was also implemented to explore students' attitudes on the treatment - peer video recording task-based approach. The study's results revealed that students in the group treated with peer video recording task-based approach significantly outperformed those in the control group in terms of fluency, grammar, pronunciation and interactive communication while students' vocabulary score remained after the treatment. In addition, the data obtained from the questionnaire indicated the experimental students had positive attitudes towards the peer video task-based approach. The results from the study provide grounds for some suggestions and recommendations for the teachers, the students as well as the teaching and learning speaking in Vietnam.
\end{abstract}

Keywords: peer video recordings, task-based approach, speaking performance, speaking skills, peer video reviews

\section{Introduction}

English is now widely used as an international language for communication, science, information, business and technology, and even diplomacy. It is used for global communications by a quarter of the world's population (Robson, 2013). As a matter of fact, more and more people will be using it or learning to use it for their business or daily life as a means to express themselves to the world. With this perspective, teachers of English need to find ways to enhance their teaching methods effectively. In addition to the cognitive demand and providing students with opportunities to use the language outside of the class, language educators need to find ways to extend the speaking practice out of class to expose their learners to the target language more, rather than merely rely on in-class activities (O’Malley \& Pierce, 1996). One of the ways that has received considerable attention from educators and researchers is video creating. Besides, the application of video recordings in the EFL classrooms has become more convenient due to the invention and innovation of the latest technology, making it possible for students to make their own educational videos, to record and view their performances in English.

In the context of Vietnamese, teaching and learning speaking skills have not been highly focused on. In former studies, Do (2007) finds those teachers who concentrate on presenting lexical and grammatical structures probably do not have sufficient time to organize other necessary activities or they cannot recognize the importance of other skills. Moreover, Sullivan and McIntosh (1996) revealed that teachers get used to the traditional lecture method which is a passive, one-way method of transferring information. Meanwhile, students of English as a Foreign Language (EFL) often have limited opportunities to practice speaking in an authentic and meaningful way inside and outside of the classroom (Nakazawa, Muir, \& Dudley, 2007). Unfortunately, although issues concerning the teaching and learning L2 speaking skills using technology have received a great interest from educational researchers domestically and internationally and there have been numerous studies related CALL, to the best of the researcher's limited knowledge and cautious observation, there are very few studies which have been devoted to 
exploring the effects of peer video recording task-based approach. After observing, searching and researching a number of Master Theses, the researchers found that none had been found. For the vital aforementioned issues, the researcher herself found the passion, the necessity and the urgency to conduct this empirical study.

\section{Literature Review}

The word task is from Old North French 'tasque' which means duty, tax or piece of work imposed as a duty. The Cambridge Advanced Learner's Dictionary (1995, cited by Littlewood, 2004) in the article defines a task as a piece of work to be done especially one done regularly. Regarding definitions from trustworthy writers, Prabhu (1987) considers a task is an activity which required learners to arrive at an outcome from given information through some process of thought, and which allowed teachers to control and regulate that process. Lee (2000) defines a task as (1) a classroom activity or exercise that has: (a) an objective obtainable only by interaction among participants, (b) a mechanism for structuring and sequencing interaction, and (c) a focus on meaning exchange; (2) a language learning endeavor that requires learners to comprehend, manipulate, and/or produce the target language as they perform some sets of work plans. Bygate, Skehan, and Swain (2001) view the task as an activity that requires learners to use language, with emphasis on meaning, to attain an objective.

Task-based Approach (TBA) is also called Task-based Instruction (TBI) or Task-based Language Teaching (TBLT) was born out of "Bangalore Project" that started in 1979 and ended in 1984 by Prabhu in India from the aspect of teaching, stressing that students study languages by fulfilling the tasks in the process of language use. It has caught a lot of attention from educators and scholars in the Second Language Acquisition (SLA) since then. According to Jack (2001), Task-Based Language Teaching (TBLT) refers to an approach based on the use of tasks as the core unit of planning and instruction in language teaching. Skehan (1996), a well-known British linguist, defined TBI as "Instruction in which learners are given tasks to complete in the classroom makes the assumption that transacting tasks in this way will engage naturalistic acquisition mechanisms, cause the underlying inter-language system to be stretched, and drive development forward" (p. 95). Willis (1996) thinks that Task-based Language Teaching (TBLT) is an effective method to English learning and teaching which takes advantage of tasks assigning language learners in a given context and encourages them to finish those tasks for the purpose of communication.

Willis (1996) wrote that a Task-based approach is a teaching approach using tasks as its main pedagogical implements to organize language teaching. Experts support the viewpoint that the task-based approach is the clear enhancement of Communication Linguistics in that they have related principles in teaching. To illustrate, they both admit that activities for real communication are vital in language learning; meanwhile, they both admit that utilizing language to perform meaningful tasks can enhance language learning; they also both admit that the language which is meaningful to learners can pave the way for the learning process. According to Lin (2009), the task-based approach is a powerful and advancing learning method, which promotes learning language knowledge and training skills in the process of performing tasks. Through TBLT, learners will master how to make full use of their own communicative abilities to shift from their mother tongue to the target language. It presents a chance for them to learn cooperatively and activate their probable abilities to employ and deal with the target language in a professional way.

Saying the words out loud rather than in their head gives students more confidence to speak in public (Kim, 2014; Nazlinur, 2016). Tapscott (1998) and Fredenberg (2008) wrote in their studies that video files were convenient to practice with, especially at home or outside because they are significantly lighter than textbooks. Next, creating some one's content is a valuable learning experience and makes their learning more enjoyable (Nazlinur, 2016; Hsu et al., 2008; Skiba, 2007; Gehringer \& Miller, 2009; Fredenberg, 2008). In Jeremy (2015), the camera (and/or the microphone) can become a central learning aid, as a result of which students work cooperatively together using a wide variety of language both in the process and the product of making a video or audio recording. In an attempt to provide learners with opportunities to improve chances of speaking, fluency and motivation outside the classroom, Pop, Tomuletiu and David (2011), Swain and Lapkin (1995) and Nazlinur's (2016) pointed out that video recordings offer students a chance to observe the leap of improvement in their speeches, which, in turn, gave them a sense of accomplishment. Mennim (2003) suggested that rehearsed oral output and revisions of their recording after self-reflection would promote a more sophisticated and complex use of vocabulary and language form. Huang (2008) mentioned students noticing the use of simple vocabulary in their recordings. Stillwell et al. (2010) also found an increase in complexity after recording, self-assessing and revising students' oral output. In Nazlinur's (2016) study, learning new vocabulary items was a perceived gain of digital video recordings. Kırkgöz (2011) concluded that video recordings helped the learners to expand their theme-related vocabulary. Moreover, students' grammar is also mentioned. In terms of grammatical accuracy in oral output, learners generally performed better after self-reflection (Cooke, 2013; Huang, 2008; Lynch, 2007; Stillwell et al., 2010). Huang 
(2008) suggested that having students listen to non-native speakers' authentic output is one way to enhance the students' ability to focus on form. Peer video recordings also assist improve learners' phonetic articulation as part of pronunciation. Students were aware of their difficulty pronouncing specific segments of English sounds and students' attention shifted from segmental (e.g., vowels and consonants) to suprasegmentals (e.g., intonation, linking, and sentential stress) (Achiko, 2014; Lord, 2008; Ducate \& Lomicka, 2009; Brown's, 2012). Pop, Tomuletiu and David (2011) and Brown (2012) indicate that students can receive constructive written feedback and comments after they upload their recordings.

It was proven that technologies play a vital role in learning in general in learning a language in particular. Thanks to the technologies, students are less dependent on the teachers. Bohuijs (1998) claims that information technologies (e.g., computer programs/databases and internet facilities have provided students with excellent opportunities to learn without requiring a teacher to transmit the available information). Thereby peer learning is a type of paradigm of shifting from highly teacher-center to learner-center education, in which students are expected to take greater initiative and responsibility to manage more of their own learning and education or personal development.

In Vietnam, there have been several experimental studies applied technology including computers, computer aids, visual aids, instructional technology, multimedia, e-course, e-learning, internet in teaching general English and skills like reading, vocabulary and grammar (Su, 2005; Vo, 2006; Pham, 2006; Le, 2007; Phan, 2007; Dinh, 2008; Nguyen, 2008; Phan, 2010; Dao, 2008). In addition, other studies that are closely connected to applying technology in improving students' speaking skills have been conducted in years recently by Le (2010), Tran (2011) and Pham (2012).

In the world, in an attempt to help learners improve their fluency, Aldy and Rahmila (2013) conducted research reading a monologue and their voice was recorded with two classes of Intermediate 4 at LIA Banjarmasin. Concerning voice recording, Sachiko (2014) suggested that it is a potential tool by the integration of technologies such as audio-blogs and awareness-raising tasks to promote students' oral output outside the classroom as well as awareness of their performance and strengthening their sense of ownership over their learning. Huang and Hung (2010) conducted a study to explore the EFL learners' perceptions towards the use of e-portfolios as an alternative way of assessing their oral proficiency at a university in Taiwan. Castañeda and Rodríguez-González (2011) investigated the effect of self-evaluation through video portfolios on the Spanish oral performance of nine undergraduate learners in an intermediate speaking class. In Nazlinur's (2016) study, furthermore, students pointed out that sharing their videos with their friends gave them an opportunity to be involved in a real task that required the use of English. Cheng and Chau (2009) also explored the potential of digital video for fostering self-reflection in an e-portfolio mediated learning environment. Similarly, Sun (2012) conducted an exploratory study on the use of voice blogs as an extensive speaking practice in two oral communication classes as a part of a large-scale study. Another study by Ru-Chu (2010) aimed to establish a blended teaching and learning model combining online and face to face instructional blogging for an English for specific purposes (ESP) course named English Public Speaking. However, several previous studies suggest that the incorporation of digital video recording into speaking classes as an extensive practice did not improve the EFL learners' overall oral proficiency and content elaboration at a significant level (Sutudenama \& Ramazanzadeh, 2011; Baniabdelrahman, 2013). In summary, only a few studies involving speaking skills have been conducted. The majority of these studies have focused not on the actual improvement of oral proficiency as a result of the digital video recording, but the learners' perceptions of the incorporation of digital video recording into speaking classes. However, most of these studies have dealt with other skills, not speaking skills and the method is only voice recording rather than a video recording. Other studies were conducted in another foreign language rather than English. Regarding the lack of research in this area in EFL context and to confirm authors who support as well as to oppose the incorporation of digital video recording into speaking classes in improving the EFL learners' overall oral proficiency, this study was conducted.

\section{The Conceptual Framework}

The components mentioned in the literature established the conceptual framework of the study, which could be summarized as follows: 


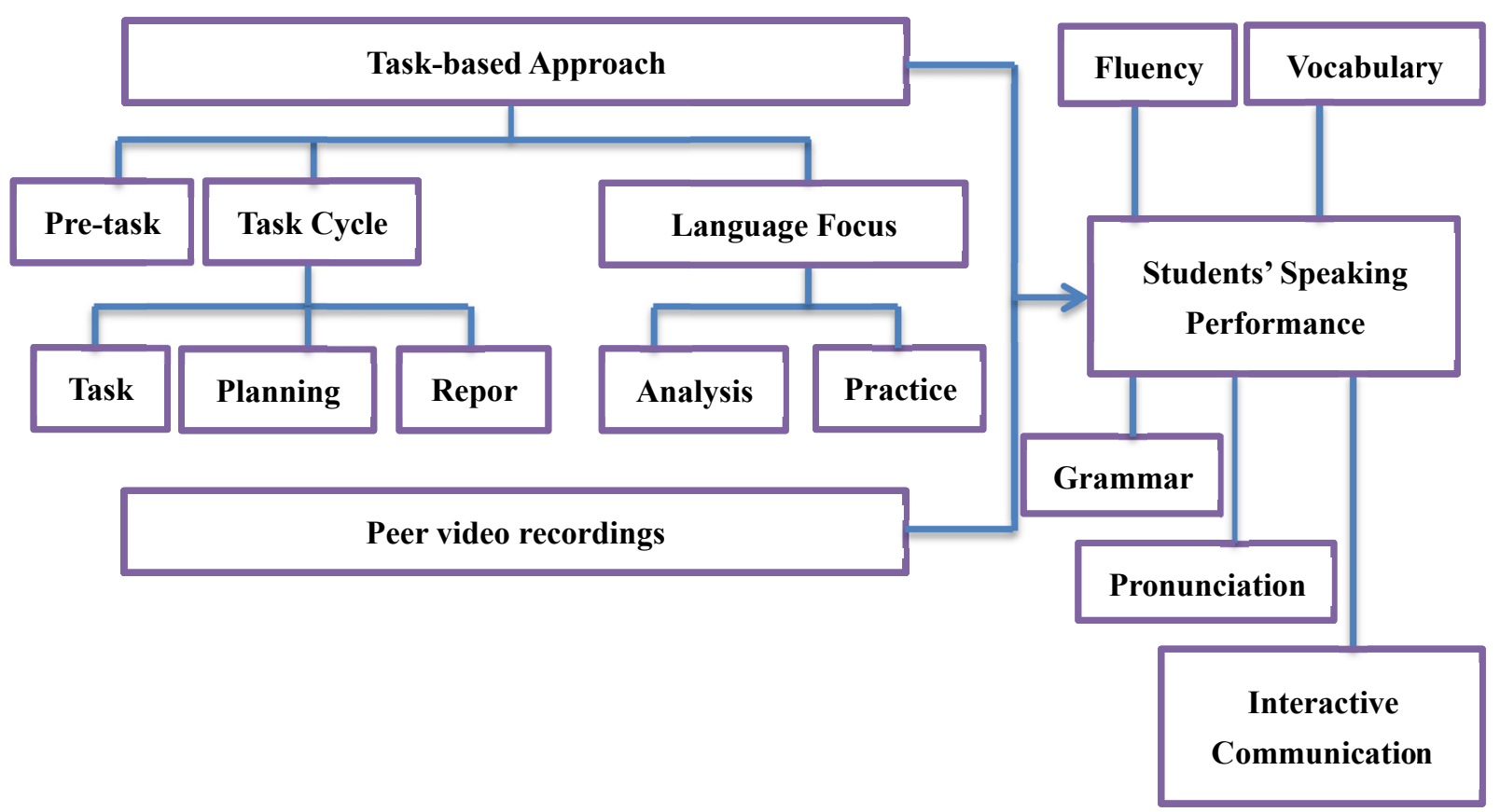

Figure 1. The conceptual framework of the study

\section{Method}

\subsection{Pedagogical Setting \& Participants}

The quantitative research methodology was used to study whether the students' speaking skills improved when the technique is applied and students' attitudes towards the technique. Two groups of students were taken in this study, a control group and an experimental one, designed as a Two-group Quasi-Experimental Design. The two groups were two intensive English classes selected from CFC with approximately forty students in each class. The participants in the study consisted of the teacher/researcher, two examiners (one foreign teacher and one Vietnamese teacher) and eighty non-English majored students in two intensive English classes.

\subsection{Training Procedure}

The research was carried out in twenty sessions with three main stages. In the first stage, the experimental group and the control group were chosen. For the first session, both groups took their pretest (written and speaking test) on the first day of their course. The questionnaire 1 used to measure students' ownership and experience in digital devices was also delivered to students in the experimental group. Afterward, students in the experimental group actively chose their partners, who would work together during the course and the research. Students would be explained and instructed with the method carefully. After the researcher collected and analyzed the first questionnaire, she trained the students on how to send their video products to the teacher; if the video was too large (exceeding 25MB), it would be uploaded onto Google Drive (https://www.google.com/drive/). In the second stage of the research model design, the peer video recordings task-based approach was applied to the experimental class and the task-based approach was applied to the control group. Lessons for both groups included four stages of the task-based framework which are pre-task, task cycle, language focus, and assigned task. In the Pre-task stage, the teacher explored the topic with the class and many highlights of useful words and phrases, helped students to understand the task instructions. The students might hear a recording of other people doing the same task. During the Task cycle stage, the students performed the task in pairs or small groups while the teacher monitors from a distance. The students then planned how they will tell the rest of the class what they did and how it went, and then they reported on the task either orally or in writing, and or compare notes on what has happened. In the Language focus stage, the students examined and discussed specific features of any listening or reading text which they have looked at for the task and/or the teacher may conduct some form of practice of specific language features which the task has provoked. The experimental class was different from the control group in the fourth stage - the assigned task. Students in the experimental class were asked to work with their peers (as assigned previously) to record one video (maximum five minutes) about a conversation/dialogue or a topic they have learned on that day in class. The teacher collected all the videos and gave some feedback and assessment. Teachers could comment on most of the 
students' videos through emails and only $20 \%$ (5 out of 20 videos) per class meeting. Teachers showed some of the videos in class for the whole class to give compliments or comments. After listening to the comments and feedback from the lecturer and their classmates, students were advised to listen or watch the video again at home at least twice. The teacher collected the videos and made an assessment every week. The experiment ended at the end of the course. In the last stage_-post-test stage, students in both groups took their speaking posttest. Figure 2 presents the framework of the research design.

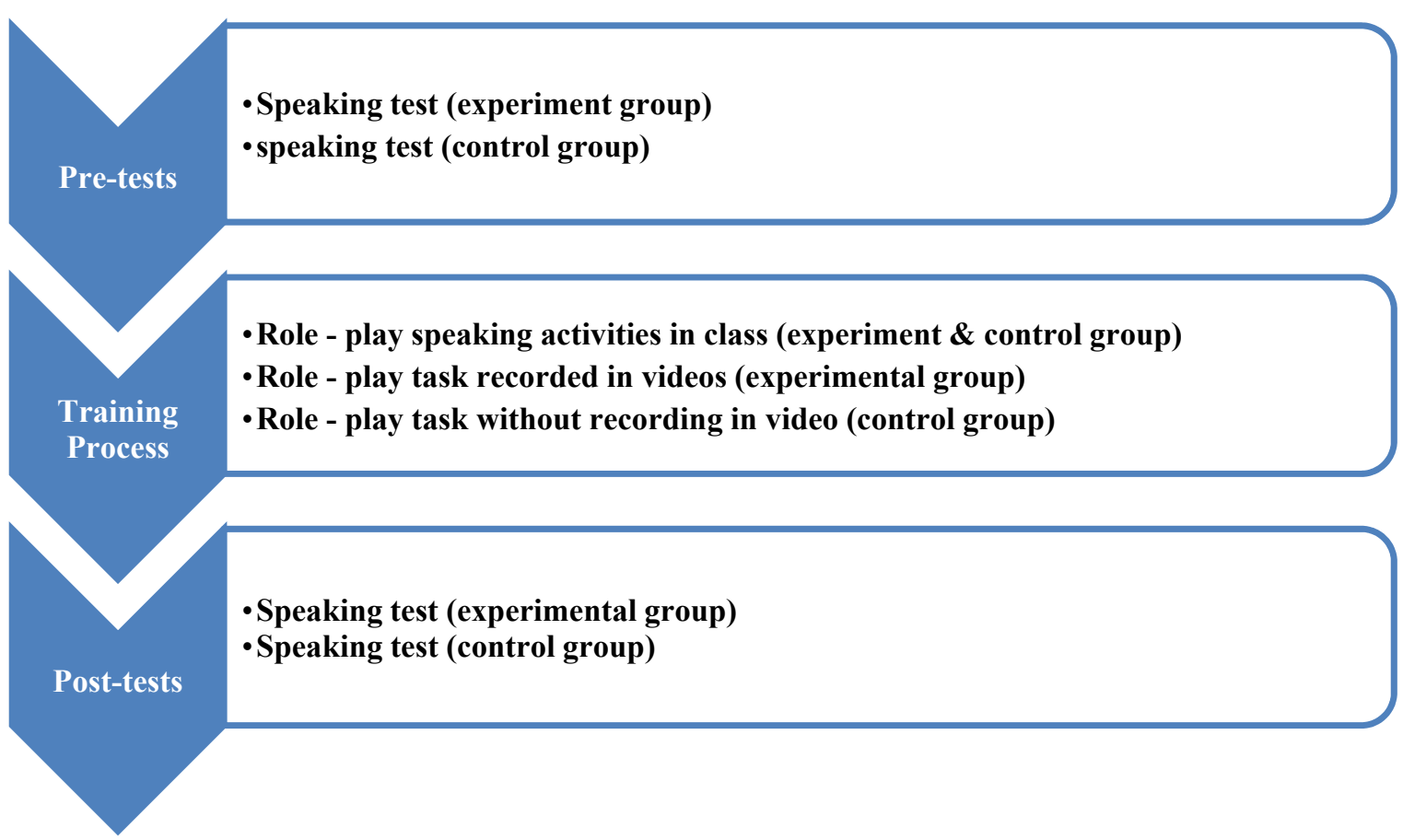

Figure 2. The framework of the study

\subsection{Research Instrument}

\subsubsection{Pre-tests}

To identify whether the students' levels are equal, a pretest was conducted at the start of the twenty-section course. The test was taken by the Cambridge English Language Assessment. The pre-test consists of written and spoken tests. In the spoken test, the students worked in pairs, and each pair had eight to ten minutes to speak with the examiners at a time. The purposes of the spoken test were not only to see if the students' speaking level was equal but also to compare with the students' results at the end of the course. The pre-test for the two groups has two parts, as follows:

Part 1: each candidate interacts with the interlocutor, using the language normally associated with meeting people for the first time, giving factual information of a personal kind, for example, name, place of origin, study, family, etc. Candidates are also expected to be able to talk about their daily lives, interests, likes, etc.

Part 2: Prompt cards are used to stimulate questions and answers of a non-personal kind. The interlocutor reads out instructions and gives a question card to one candidate and an answer card to the other. After the candidates have asked and answered the questions, they change roles.

\subsubsection{Post-Tests}

Post-tests for the study taken from the Cambridge English Language Assessment were conducted on the final day of the course. The post-tests were administered by the researchers with the help of the two examiners (inter-raters). The format of the post-tests was not any different from the pretests since they needed consistency. Only the content was changed according to what students have learned during the twenty sections.

\subsubsection{Inter-Raters}

In order to assure the reliability of the results, the current study employed inter-raters to assess the students 
speaking tests. According to David et al. (1997), assessing inter-rater reliability, whereby data is independently coded and the coding compared to agreements, is a recognized process in quantitative research. This refers to the degree to which different raters give consistent estimates of the same behavior. Both raters, the researcher and a native speaker, used the analytic scale to observe and give scores on the students' performances. The scores given by the two raters were then compared to test the reliabilities. Any discrepancy would be discussed or averaged. The Pearson correlation between the inter-raters was .924 .

\subsubsection{Questionnaire}

In the field of second language research, a very popular data collection technique has been the use of various types of questionnaires. According to Wallace (1998), questionnaires are used to get the knowledge, attitudes, thoughts, and experiences from learners. The way to make questionnaires is to ask questions. The answers are usually recorded in some ways to be used for subsequence reflection and analysis. In questionnaires, the respondents read the questions, and then tick responses, or write short answers. Wallace (1998) also suggests a tip to make questionnaires. That is user-friendliness because no-one enjoys answering questionnaires. Hence, the questionnaires should be made as 'user-friendly' as possible. This means they should not be too long and intrusive (asking questions that may embarrass the respondents), and they should not be confused.

The current study employed a close-ended paper-based questionnaire. To help ensure the data collected and keep it from being influenced by any cultural factors regarding the middle point on odd-numbered scales (Chen, Lee, \& Stevenson, 1995), a 5-point Likert-scale questionnaire was implemented. Moreover, a Likert' scale was utilized for its ease of comprehensibility (for respondents) as well as its uniformity across different collection periods. The questionnaire in the current study included 2 parts. Part 1 was about students' attitudes towards the use of peer-video recording experience for learning activities from question 1 to 10 . Part 2 is related to students' attitudes towards the effects of peer video recordings from question 11 to 24. The Cronbach's Alpha of 24-questionnaire reached .79 .

\subsubsection{Data Collection \& Analysis}

The data in the study are quantitative data taken from the two oral tests and the questionnaire. The pre-test data were collected at the beginning of the course and the post-test data and the questionnaire was collected at the end of the course. Both individual and pair-sample t-tests were run to investigate whether there were any differences between the students' scores before and after the training. The Likert' scale questionnaire was analyzed by mean scores with the Descriptive statistics. The results and findings would be presented in the following sessions.

\section{Results/Findings and Discussion}

Pretest scores of 80 of both groups were compared and analyzed. Independent Sample t-test was run to compare the results of two groups from the beginning of the course before the researcher carries out the experiment to see if it is effective or not. Two classes were asked to take one written test and one speaking test. The correlation coefficient of the scores between inter-raters reached .924**. Correlation is significant at the 0.01 level (2-tailed). The following table shows the results of the pretests.

Table 1. Comparing the oral tests of the experiment and control group

\begin{tabular}{lccccc}
\hline Variable & $\mathrm{M}$ & $\mathrm{SD}$ & $t$ & $d f$ & $p$ \\
\hline Speaking Pretest & & & & & \\
Experimental group & 4.96 & 0.61 & .08 & 78 & .93 \\
Control group & 4.98 & 1.25 & & & \\
\hline
\end{tabular}

Note. The $t$ and $d f$ were not adjusted because the variances were equal. Independent Samples T-test.

As presented in Table 1, the mean score of 40 students of the experiment group and 40 students of the control group were compared by Independent Samples t-test. The Mean score of the experimental group was $4.96(\mathrm{M}=$ 4.96) and of the control group was $4.98(\mathrm{M}=4.98)$. It seems that the Mean score of the control group was slightly higher than that of the experimental group. However, the result of the Independent Samples t-test shows that the two groups were not significantly different in their English proficiency $(p=0.93>5 \%)$. This means that students' speaking performance ability in the two groups was equal. Therefore, two group samples were proportional and met the requirements to be conducted in this study. Moreover, if there was a significant difference in the students' speaking scores of the two groups after the treatment, it could be predicted that there was an effect of the independent variable (peer video recording) on the dependent variable (students' speaking scores). 


\subsection{Research Question 1: To What Extent Does Peer Video Recording Task-Based Approach Affect Students' Speaking Skills?}

In response to this research question, independent and pair-sample t-tests were run to test the differences of pre- vs. post-tests of the two groups. Cronbach's alpha for the inter raters of the control groups at the beginning of the course was .84 and at the end of the course was 0.82 . Table 2 presents the comparison of the pre- vs. post-test scores of the control group on students' speaking performance.

Table 2. Comparing students' speaking scores of the control group

\begin{tabular}{llllllll}
\hline Variable & M & SD & Correlation & Mean difference & $t$ & $d f$ & $P$ \\
\hline Control Group & & & & & & & \\
Speaking Pretest & 4.98 & 1.25 & .39 & -.3 & -3.7 & 39 & .18 \\
Speaking posttest & 5.28 & 0.13 & & & & \\
Paired Samples T-test & & & & & & \\
\hline
\end{tabular}

The results from Table 2 show that 40 students in the control group had little improvement in the post-test (the mean score rises from 4.98 to 5.28). The mean difference between the two tests was -.3. However, the results of the Paired Samples t-test show that there was no significant difference of the students' speaking scores in the pretest and posttest when the $\mathrm{t}(39)=-3.7$, sig $=0.18>$ alpha $(5 \%)$. Therefore, according to the statistics, the writer of this study could conclude that the role-play traditionally did not have much influence on students' speaking performance, and if there was, there was not much. In other words, there was no significant difference in the quality of students' speaking ability in the control group. Table 3 presents a comparison of the pre- vs. post-test scores of the experimental group on speaking performance.

Table 3. Comparing students' speaking scores of the experimental group

\begin{tabular}{lccccccc}
\hline Variable & M & SD & Correlation & Mean difference & $t$ & $d f$ & $p$ \\
\hline Experimental Group & & & & & & & \\
Speaking Pretest & 4.96 & 0.61 & .39 & -5.77 & .08 & 78 & .004 \\
Speaking posttest & 7.98 & 0.28 & & & & \\
Paired Samples T-test & & & & & & & \\
\hline
\end{tabular}

Table 3 displays the results of comparing the students' speaking skills between the beginning of the course and the end of the course of the experimental group. Cronbach's alpha of the inter raters of the experimental group at the beginning of the course reached 0.79 and at the end of the course was 0.72 . The Mean score of 40 students in the pretest was $4.96(\mathrm{M}=4.96)$. The Mean score of 40 students in the posttest was $7.98(\mathrm{M}=7.98)$. Paired Samples T-test found out that the statistic number $\mathrm{t}(39)=-5.77$, sig. $=0.04<$ alpha $(5 \%)$. This indicates that making a peer video has radically influenced students' speaking skills. Table 4 presents the comparison between the pre- vs. post-test scores in terms of the speaking elements of the experimental group.

Table 4. Comparing students speaking elements' scores of experimental group

\begin{tabular}{lllll}
\hline Variables & Pretest $M$ & Posttest $M$ & Mean Diff. & Sig. (2-tailed) \\
\hline Experimental Group & & & & \\
Fluency Pretest & 0.85 & 1.86 & -.725 & .000 \\
Grammar & 1.02 & 1.33 & -.31 & .021 \\
Vocabulary & 1.06 & 1.06 & .000 & 1.00 \\
Pronunciation & 1.18 & 1.85 & -.67 & .000 \\
Interactive Communication & 1.25 & 1.98 & -.73 & .000 \\
Paired Samples T-test & & & & \\
\hline
\end{tabular}

Table 4 reveals the comparison between the pretest and posttest mean scores of the Experimental Group in terms of fluency, grammar, vocabulary, pronunciation and interactive communication. It also reveals Sig. for the comparison of the average scores of pretest and posttest. Most posttest scores were higher than pretest scores except for the Vocabulary criterion, in which pretest and posttest mean score was $1.06(\mathrm{M}=1.06)$. This indicates that the mean difference was .0. Moreover, Sig. for the comparison of the average scores of pretest and posttest was 
$\mathrm{p}=1.00>\alpha(5 \%)$. Thus, the difference in pretest-posttest scores was statistically zero. This was opposite with the results obtained in Sun (2012), Huang and Hung (2010), Castañeda and Rodríguez-González (2011), Huang (2008), Nazlinur (2016), Kırkgöz (2011) and Mennim (2003). According to these authors, the learners sometimes got stuck in their speeches due to lack of some topic-related vocabulary items at their disposal, and they had to shoot the videos one more time after they looked up the unknown words. Furthermore, they could easily recall the words that they used during their video recordings after two or three weeks, which indicates that digital video recordings created a learning opportunity for them and helped them to access new vocabulary items easily. Video recordings also helped the learners to expand their theme-related vocabulary. However, this treatment failed to improve students' vocabulary because the students will not have the vocabulary to start with. Instead, they will only have what they know instead.

For the Fluency criterion, the pretest mean score was $0.85(\mathrm{M}=0.85)$, the posttest mean score was $1.86(\mathrm{M}=1.86)$, this indicates the mean difference was -.725 and the Sig. for the comparison of the average scores of pretest and posttest was as $\mathrm{p}=.00<\alpha(5 \%)$. Thus, the difference in pretest-posttest scores was a statistically significant difference, and we could tell from the means in Table 4 that posttest scores were higher. This result follows Skehan (1996), Aldy and Rahmila (2013), Castañeda and Rodríguez-González (2011), Nazlinur's (2016) and Sun (2009) that to achieve the first goal, fluency, learners aim to use the target language in real-life situations at an adequate degree of speech rate without disturbing pauses. The result is, through this procedure most of the students were able to improve their reading fluency, as evidenced by their correct use of chunking, phrasing, intonation, and word stress. The learners from those reports said that they perceived an improvement in their speaking skills, in particular in fluency, rather than accuracy.

For the Grammar criterion, the pretest mean score was $1.02(\mathrm{M}=1.02)$, the posttest mean score was $1.33(\mathrm{M}=$ 1.33), this indicates the mean difference was -.31 and the Sig. for the comparison of the average scores of pretest and posttest was as $\mathrm{p}=.021<\alpha(5 \%)$. Thus, the difference in pretest-posttest scores was statistically significant. This result was consistent with results from Cooke (2013), Huang (2008), Lynch (2007), Stillwell et al. (2009) and Huang (2008). suggested that having students listen to non-native speakers' authentic output is one way to enhance the students' ability to focus on form. Lynch (2007) noted that the class in which students initiated self-transcribing and self-reflection outperformed inaccuracy. According to Pham and Nguyen (2014), training students on how to learn grammar with CLT could improve their grammatical knowledge and performance. Therefore, students could have simply memorized the revised dialogues and presentations. Yet, the students could use the grammatical knowledge they learn and they could use them correctly.

For the Pronunciation criterion, the pretest mean score was $1.18(\mathrm{M}=1.18)$, the posttest mean score was $1.85(\mathrm{M}=$ 1.85 ), this indicates the mean difference is -.67 and the Sig. for the comparison of the average scores of pretest and posttest as $\mathrm{p}=.00<\alpha(5 \%)$. Thus, the difference in pretest-posttest scores is statistically very significant. Research results specific to pronunciation using voice recording have been revealed by Achiko (2014), Lord (2008), Ducate and Lomicka (2009). The results suggested that students' phonetic articulation improved after the project. Moreover, students' attitudes towards pronunciation also improved. Students can receive constructive written feedback and comments after they upload their recordings. In Brown's (2012) study, students were aware of their difficulty pronouncing specific segments of English sounds. As the project progressed, students' attention shifted from segmental (e.g., vowels and consonants) to suprasegmentals (e.g., intonation, linking, and sentential stress). The recording project was viewed as a success in enhancing the students' intelligibility. In terms of their attitudes and perception of improvement, the post-project questionnaire revealed that the students appreciated the extra opportunities of oral output outside the classroom and felt that their pronunciation did indeed improve. These studies imply that recordings alone cannot improve pronunciation significantly. Consistent instruction and practice in class are needed in combination with using recordings.

For the Interactive Communication criterion, the pretest mean score is $1.25(\mathrm{M}=1.25)$, the posttest mean score is $1.98(\mathrm{M}=1.98)$, this indicates the mean difference is -.73 and the Sig. for the comparison of the average scores of pretest and posttest as $\mathrm{p}=0.000<\alpha(5 \%)$. Thus, the difference in pretest-posttest scores is statistically very significant, and we can tell from the means in Table 4 that posttest scores are higher.

In summary, with the exception of Vocabulary scores, the remaining posttest scores are higher than their pretest scores. Students' interactive communication skills have improved the most; the following are Fluency skill and Pronunciation. Students' Grammar skills have also improved but with little change. Opposing to the experimental group, there is no considerable improvement of the control group before and after the treatment.

The next step to prove the first question is comparing the posttest results of the control group and the experimental group. 
Table 5. Comparing posttest results of the two groups

\begin{tabular}{lccccc}
\hline Variable & $\mathrm{M}$ & $\mathrm{SD}$ & $t$ & $d f$ & $p$ \\
\hline Speaking Posttest & & & & & \\
Experimental group & 7.98 & 0.28 & .08 & 78 & .035 \\
Control group & 5.28 & 0.13 & & & \\
Independent Samples T-test & & & & & \\
\hline
\end{tabular}

Table 5 reveals the comparing posttest results of the two groups (control and experimental group). The Independent Samples t-test was run to compare the results. From the table above, we could draw the sig. $=.035<$ alpha (5\%). Therefore, we could conclude that the result of the Independent Samples t-test shows that the speaking skills of the two groups were a statistically significant difference. This means that recording a peer video has influenced substantially on students' speaking skills. Explicitly, students' speaking means score in the experimental class has changed approximately 3 points from 4.96 to 7.98 . However, not all the five criteria of the speaking performance have improved. With the exception of Vocabulary scores, the remaining posttest scores were higher than their pretest scores. Students' interactive communication skill has improved the most followed by Fluency skill and Pronunciation. Students' Grammar skills have also improved but with little change. On the contrary, without the peer video recording, students' speaking performance in the control group did not have a significant difference despite little change. Explicitly, students' speaking means the score has changed from 4.98 to 5.28. The results of this study confirmed Pham and Usaha's (2016) that in case the teacher knew how to make use of the effective technological tool in the classroom to train the students, the students would gain many benefits from it for their language development.

\subsection{Research Question 2: What Are Students' Attitudes Towards Peer Video Recording Task-Based Approach?}

The answer to the second research question was taken from the quantitative data from the Questionnaire. They were analyzed in terms of Mean (M), Standard Deviation (SD) to find out the students' attitudes towards peer video recordings. First, the internal consistency reliability was assessed by computing Cronbach's alpha. Alpha reliability as relatively accepted $(\alpha=.786)$ which was deemed adequate. The questionnaire designed to collect data for this research question was composed in 5-point Likert-scale from 1 (strongly agree) to 5 (strongly disagree). Responses ranged from 1.00 to 2.60 were seen as highly evaluated; from $2.61-3.40$ as a medium; and from 3.415.00 as low evaluation. Table 5 presents the student's perception of the employment of peer video recording for learning activities.

Table 6. Students' attitudes towards the employment of peer-video recording for learning activities

\begin{tabular}{lllll}
\hline Item & The employment of peer-video recording & N & M & SD \\
\hline $\mathbf{1}$ & I was eager about peer video recordings. & 40 & 2.02 & .768 \\
$\mathbf{2}$ & I took notes and followed all of my lecturer's instructions. & 40 & 2.53 & .716 \\
$\mathbf{3}$ & I could easily choose my partner for the pair work. & 40 & 2.88 & .686 \\
$\mathbf{4}$ & I could send my video to my lecturer easily. & 40 & 1.60 & .709 \\
$\mathbf{5}$ & Making a video was not problematic for me. & 40 & 1.53 & .599 \\
$\mathbf{6}$ & Editing a video that was not problematic for me. & 40 & 2.10 & .545 \\
$\mathbf{7}$ & Speaking in the video was not problematic to me. & 40 & 2.68 & .474 \\
$\mathbf{8}$ & I watched my videos several times. & 40 & 3.60 & .496 \\
$\mathbf{9}$ & I did not make the same mistakes for the subsequent videos. & 40 & 3.23 & .480 \\
$\mathbf{1 0}$ & I applied what my lecturer advised into speaking in the videos. & 40 & 1.85 & .533 \\
Valid & N (Listwise) & 40 & & \\
\hline
\end{tabular}

Table 6 shows that most of the respondents carried out the treatment quite well with the highest extent (items 1, 2, $4,5,6$ and 10; $\mathrm{M}=2.02,2.53,1.60,1.53,2.10$, and 1.85). Most students said that they were eager when the lecturer told their class about peer video recordings. They also took note and followed all of their lecturer's instructions in doing peer video recordings. They could send their videos to their lecturer easily. Making and editing a video was not problematic for the students. The final item which received a high extent from students' answer is item 10, students applied what their lecturer advised them into speaking in the videos.

Table 6 also showed us a medium answer from students especially items 3, 7 and 9. In item 3, students said that they can easily choose their partner for the pair work. But the results for this item received only a medium extent. In Item 7, the students said that speaking in the video was not problematic for them. It seems impossible to ensure 
that students do not have any difficulties in speaking in the videos without a doubt. Such difficulties can be projected such as feeling shy or they do not know where to look at. In item 9, they did not make the same mistakes for the subsequent videos. This corresponds to what the researcher observed during the course, students keep making the same minor mistakes. However, there was a turnaround when fewer mistakes were made in the last videos.

Item 8 received a low answer from students with a mean score of 3.60. It is pretty sure that students do not agree that they watched their videos several times before they send them to their lecturer. Despite being eager and following most of the lecturer's instructions, students still admit that watching their videos again is a tough job to do.

Table 7. Students' attitudes towards the effects of peer video recordings

\begin{tabular}{lllll}
\hline Item & The effects of peer-video recordings & N & M & SD \\
\hline $\mathbf{1 1}$ & Peer video recordings made me more confident to speak English. & 40 & 1.85 & .533 \\
$\mathbf{1 2}$ & Video files were convenient to practice with. & 40 & 1.55 & .513 \\
$\mathbf{1 3}$ & Creating my own content was a valuable learning experience. & 40 & 2.60 & .686 \\
$\mathbf{1 4}$ & Peer video recordings helped me develop pair work and teamwork. & 40 & 2.33 & .616 \\
$\mathbf{1 5}$ & Peer video recordings made my learning more enjoyable. & 40 & 1.95 & .639 \\
$\mathbf{1 6}$ & Peer video recordings increased my productivity. & 40 & 1.95 & .552 \\
$\mathbf{1 7}$ & Peer video recordings made learners more autonomous. & 40 & 1.97 & .577 \\
$\mathbf{1 8}$ & Peer video recordings motivated me to learn English. & 40 & 1.97 & .620 \\
$\mathbf{1 9}$ & Peer video recordings gave learners more opportunities to practice speaking. & 40 & 1.92 & .526 \\
$\mathbf{2 0}$ & Peer video recordings helped me improve my speaking fluency. & 40 & 1.63 & 4.955 \\
$\mathbf{2 1}$ & Peer video recordings helped me improve my vocabulary. & 40 & 1.95 & .639 \\
$\mathbf{2 2}$ & Peer video recordings helped me improve my grammar. & 40 & 1.87 & .563 \\
$\mathbf{2 3}$ & Peer video recordings helped me improve my pronunciation. & 40 & 1.85 & .580 \\
$\mathbf{2 4}$ & I gained useful feedbacks on my speaking mistakes through Peer video recordings. & 40 & 1.90 & .632 \\
Valid & N (Listwise) & 40 & & \\
\hline
\end{tabular}

Table 7 is the result of the students' attitudes towards the treatment that the researchers applied in their English class - students make videos in pairs to record their conversations, calculated by SPSS. Although these results protested the results from several previous studies which suggest that the incorporation of digital video recording into speaking classes as an extensive practice did not improve the EFL learners' overall oral proficiency and content elaboration at a significant level (Sutudenama \& Ramazanzadeh, 2011; Baniabdelrahman, 2013), a great number of authors correspond to this result. Detailed results and discussion will be presented by items as follows:

Students agree that peer video recordings made them more confident to speak English $(\mathrm{M}=1.85, \mathrm{SD}=.533)$. Students show positive attitudes towards the statement "video files were convenient to practice with $(\mathrm{M}=1.55, \mathrm{SD}$ $=.513)$. Most students agree that creating their own content was a valuable learning experience. $(\mathrm{M}=2.60, \mathrm{SD}$ $=.686)$. Students also agree that peer video recordings helped them develop pair-work and teamwork $(\mathrm{M}=2.33$, $\mathrm{SD}=.616)$. "Peer video recordings made my learning more enjoyable" received positive answers from the students $(\mathrm{M}=1.95, \mathrm{SD}=.639)$. Most students say that peer video recording increased their productivity $(\mathrm{M}=1.95$, $\mathrm{SD}=.552)$. Students agree that peer video recordings made them more autonomous $(\mathrm{M}=1.97, \mathrm{SD}=.577)$. Peer video recordings also motivated students to learn English $(\mathrm{M}=1.97, \mathrm{SD}=.620)$. "Peer video recordings gave learners more opportunities to practice speaking" $(\mathrm{M}=1.92, \mathrm{SD}=.526)$ and have more opportunities to practice speaking means that having more time to practice speaking at home or outside the classroom. This result repeats the result of Solanki and Phil (2012), Fredenberg (2008), Kim (2014), Hsu et al. (2008), Henry and Cheryl (2012), Skiba (2007), Gehringer and Miller (2009), Jeremy (2015), Skiba (2007), Castañeda and Rodríguez-González (2011) Pop, Tomuletiu and David (2011), Swain and Lapkin (1995), Danny Huang and Alan Hung's (2010), and Nazlinur (2016).

Fluency is the first of five scoring criteria in the speaking test, which received highly positive answers from students $(\mathrm{M}=1.63, \mathrm{SD}=.955)$. This result follows Skehan (1996), Aldy and Rahmila (2013), Castañeda and Rodríguez-González (2011), Nazlinur's (2016) and Sun (2009). Affirmatively, as regards the learners' perceptions on the effectiveness of digital video recording on their oral communication skills, the findings revealed that, interestingly, the learners have a positive attitude towards an improvement in their use of vocabulary $(\mathrm{M}=1.95$, $\mathrm{SD}=.639$ ) which is consistent with the results obtained in Sun (2012), Danny Huang and Alan Hung (2010), Castañeda and Rodríguez-González (2011), Huang (2008), Nazlinur (2016), Kırkgöz (2011) and Mennim (2003). 
In terms of grammatical accuracy in oral output $(\mathrm{M}=1.87, \mathrm{SD}=.563)$, learners generally performed better after self-reflection (Cooke, 2013; Huang, 2008; Lynch, 2007; Stillwell et al., 2009). Huang (2008) suggested that having students listen to non-native speakers' authentic output is one way to enhance the students' ability to focus on form. Lynch (2007) noted that the class in which students initiated self-transcribing and self-reflection outperformed inaccuracy. Therefore, students could have simply memorized the revised dialogues and presentations. Yet, the students can use the grammatical knowledge they learn and they can use them correctly (M $=1.85, \mathrm{SD}=.580)$. Research results specific to pronunciation using voice recording have been revealed by Achiko (2014), Lord (2008), Ducate and Lomicka (2009). The results suggested that students' phonetic articulation improved after the project. Moreover, students' attitudes towards pronunciation also improved. Students can receive constructive written feedback and comments after they upload their recordings. Students said that they gained useful feedback on their speaking mistakes through peer video recording $(\mathrm{M}=1.90, \mathrm{SD}=.632)$. In recording activities, feedback from teachers and peers seems to have a positive influence on the speaking performance of learners. Likewise, In Pop, Tomuletiu and David (2011), Castañeda and Rodríguez-González (2011), Cheng and Chau (2009), and Nazlinur's (2016), students' opinions and reactions were very positive, and they were actively engaged because it allows the rehearsal and editing of audio posts, and can also help save face and build confidence. Expectations of receiving feedback from their peers and teachers motivated the learners as well. Students gain feedback from teachers, friends and themselves (self-evaluation/self-reflection). The digital video recordings helped them to realize the common use of pause fillers and hesitation markers in their own speeches and how those disfluency markers in their speeches irritated them as listeners. More specifically, in Nazlinur's (2016) study, furthermore, students pointed out that sharing their videos with their friends gave them an opportunity to be involved in a real task that required the use of English. Thus, they had a chance to watch others' performances and learn from one another.

\section{Conclusion}

Results from the Paired Samples T-test of the pretest and posttest total scores indicated both groups made improvements in their speaking test scores. However, the Independent Samples T-tests of the posttest scores of the two groups revealed that the students from the experimental group performed better than the control group. From these answers, the researcher can confirm that there is a significant difference in students' speaking skills after the treatment of peer video recordings. Responses to the questionnaire 2 delivered to the experimental group at the end of the course clarified that in general, students expressed their positive attitudes towards the effect of the treatment, in which most students said that they were eager when the lecturer told their class about peer video. They also took note and followed all of their lecturer's instructions in doing peer video recordings. They agree that they can easily choose my partner for the pair-work. Editing and speaking in the video were not problematic to the students. Those ideas received the highest praise from students while watching their videos several times and not making the same mistakes for the subsequent videos received neutral answers from students, which is, therefore, concluded that almost all students have positive attitudes towards the treatment of peer video recordings.

Although the study has satisfactory science, there exist limitations in the present study. The first and foremost weakness of this study is the fact that it employs a quasi-experimental design, instead of a truly experimental one. Additionally, the validity and reliability of this study would increase if data for the second research question was collected through various data collection techniques.

Despite satisfactory scientific results, limitations in the present study exist. Therefore, the researcher has a desire to provide a respected recommendation for future studies. It is suggested to employ a true experimental rather than a quasi-experimental design, in which the participants are randomly selected and the data for the second aim should be collected through various data collection techniques. Furthermore, future studies should cover more videos in a course and change the way students submit their videos. Instead of sending such videos through emails that waste teacher's time in receiving and downloading those videos, teachers can create a folder namely "Videos" and number the video folder on the database, then, sending the link to open these folders to their participants.

\section{References}

Aldy, R. N., \& Rahmila, M. (2013). Improving students' fluency through voice recording. Banjarmasin: LIA CAR Journal.

Baniabdelrahman, A. A. (2013). Effect of using internet tools on enhancing EFL students' speaking skill. ELT Journal, 55(2).

Bohuijs, P. A. J. (1998). The Teacher and Self-Directed Learners. In B. Jolly \& L. Rees (Eds.), Medical Education in the Millennium. Oxford: Oxford University Press. 
Boud, D., Cohen, R., \& Sampson, J. (2014). Peer learning in higher education: Learning from and with each other. Australia: The University of Technology. https://doi.org/10.4324/9781315042565

Brown, B. (2012). Raising student awareness of pronunciation and exploring out-of-class approaches to pronunciation practice. Research Notes, 48, 18-23.

Bygate, M., Skehan, P., \& Swain, M. (Eds.). (2001). Researching pedagogic tasks: Second language learning, teaching, and testing. London, England: Longman.

Cambridge University Press. (2008). Cambridge advanced learner's dictionary (3rd ed.). Cambridge: Cambridge University Press.

Casta-eda, M., \& Rodríguez-González, E. (2011). L2 speaking self-ability perceptions through multiple video speech drafts. Hispania, 94(3), 483-501.

Chen, C., Lee, S. Y., \& Stevenson, H. W. (1995). Response style and cross-cultural comparisons of rating scales among East Asian and North American students. Psychological Science, 6(3). https://doi.org/10.1111/j.1467-9280.1995.tb00327.x

Cheng, G., \& Chau, J. (2009). Digital video for fostering self - reflection in an ePortfolio environment. Learning, Media and Technology, 34(4). https://doi.org/10.1080/17439880903338614

Cooke, S. D. (2013). Examining transcription, autonomy and reflective practice in language development. RELC Journal, 44(1). https://doi.org/10.1177/0033688212473271

Dao, N. D. M. (2008). Using visual aids teach Enghlish grammar at Boston Language School in HCMC. M.A. Thesis at USSH, Vietnam National University - HCM City.

David, A., Ann, G., John, W., \& Theresa, M. (1997). The place of inter-rater reliability in qualitative research: An empirical study. Sociology, 31(3). https://doi.org/10.1177/0038038597031003015

Dinh, T. N. H. (2008). E course-A task-based approach for teaching and learning general English at Da Lat University. M.A. Thesis at USSH, Vietnam National University - HCM City.

Do, T. M. C. (2007). Teaching listening comprehension at Food Industry College of Ho Chi Minh City. Master thesis, USSH - HCM City, Vietnam.

Ducate, D., \& Lomicka, L. (2009). Podcasting: An effective tool for honing language students' pronunciation? Language Learning \& Technology, 13(3).

Ellis, R. (2003). Task-based language teaching and learning. Oxford, UK: Oxford University Press.

Fredenberg, M. (2008). Principles and pedagogy, The two Ps of podcasting in the information technology classroom. Information Systems Education Journal, 6(6).

Galloway, N., \& Rose, H. (2015). Introducing global Englishes. Routledge. https://doi.org/10.4324/9781315734347

Gehringer, E. F., \& Miller, C. S. (2009, March). Student-generated active-learning exercises. SIGCSE (Computer Science Education) Bulletin, 41. https://doi.org/10.1145/1539024.1508897

Harmer, J. (2015). The practice of English language teaching. England: Person United Kingdom.

Hsu, H. Y., Wang, S. K., \& Comac, L. (2008). Using audioblogs to assist English-language learning: An investigation into student perception. Computer Assisted Language Learning, 21(2). https://doi.org/10.1080/09588220801943775

Huang, H. T. D., \& Hung, S. T. A. (2010). Implementing electronic speaking portfolios: Perceptions of EFL $\begin{array}{lllll}\text { students. } & \text { British Journal of Educational Technology, }\end{array}$ https://doi.org/10.1111/j.1467-8535.2009.00996.x

Huang, S. C. (2008). Raising learner-initiated attention to the formal aspects of their oral production through transcription and stimulated reflection. IRAL-International Review of Applied Linguistics in Language Teaching, 46(4). https://doi.org/10.1515/IRAL.2008.016

Keith, J. T. (2005). Trends in peer learning. Educational Psychology, 25(16). https://doi.org/10.1080/01443410500345172

Kim, S. H. (2014). Developing autonomous learning for oral proficiency using digital storytelling. Language Learning \& Technology, 18. 
Kirkgöz, Y. (2011). A blended learning study on implementing video recorded speaking tasks in task-based classroom instruction. TOJET, 10(4), 1-13.

Le, P. A. (2010). E-learning application in teaching speaking English to first year students of Foreign Language Faculty at the UTE, HCM. M.A. Thesis at USSH, Vietnam National University - HCM City.

Le, T. T. P. (2007). The impact of instructional technology on autonomous learning. M.A. Thesis at USSH, Vietnam National University - HCM City.

Lee, J. (2000). Tasks and communicating in language classrooms. Boston, USA: McGraw-Hill.

Lin, Z. (2009). Task-based approach in foreign language teaching in China: A seminar paper research presented to the Graduate Faculty, University of Wisconsin-Platteville. Retrieved April 3, 2018, from http://minds.wisconsin.edu/bitstream/handle/1793/34571/Zhu,\%20Lin.pdf.txt?sequence=3

Littlewood, W. (2004). The task-based approach: Some questions and suggestions. ELT Journal, 58(4). https://doi.org/10.1093/elt/58.4.319

Lord, G. (2008). Podcasting communities and second language pronunciation. Foreign Language Annals, 41(2). https://doi.org/10.1111/j.1944-9720.2008.tb03297.x

Lynch, T. (2007). Learning from the transcripts of an oral communication task. ELT Journal, 61(4). https://doi.org/10.1093/elt/ccm050

Mennim, P. (2003). Rehearsed oral L2 output and reactive focus on form. ELT Journal, 57(2). https://doi.org/10.1093/elt/57.2.130

Nakazawa, K., Muir, H., \& Dudley, C. (2007). Is my speech improving? The use of voice boards in Japanese language learning. The International Journal of the Humanities, 5(6). https://doi.org/10.18848/1447-9508/CGP/v05i06/42148

Nazlinur, G. (2016). Examining the Effectiveness of Digital Video Recordings on Oral Performance of EFL Learners. Teaching English with Technology, 16(2).

Nguyen, T. H. (2008). The application of instructional technology in teaching listening and speaking skills. M.A. Thesis at USSH, Vietnam National University - HCM City.

Nunan, D. (1989). Understanding language classrooms: A guide for teacher-initiated action. New York: Prentice Hall.

Nunan, D. (1999). Second language teaching \& learning. Boston: Heinle \& Heinle.

O’Donnell, A. M., \& King, A. (1999). Cognitive perspective on peer learning. Lawrence Erlbaum. ISBN 0805824480.

O’Malleys, J. M., \& Valdez Pierce, L. (1996). Authentic assessment for English language learners: practical approaches for teachers. New York, NK: Addison-Wesley.

Pham, N. D. (2012). Using visual aids to motivate second - year English non-majors in speaking at Vietnamese American Vocational Training College (VATC). M.A. Thesis at USSH, Vietnam National University HCM City.

Pham, T. T. V. (2006). The effectiveness of applying computer aids in teaching vocabulary to the second-year students at The Central Professional School of Archives and Record Management No 2. M.A. Thesis at USSH, Vietnam National University - HCM City.

Pham, V. P. H., \& Nguyen, T. B. (2014). The Effects of Communicative Grammar Teaching on Students' Achievement of Grammatical Knowledge and Oral Production. English Language Teaching, 7(6), 74-86. https://doi.org/10.5539/elt.v7n6p74

Pham, V. P. H., \& Usaha, S. (2016). Blog-based peer response for L2 writing revision. Computer Assisted Language Learning, 29(4), 724-748. https://doi.org/10.1080/09588221.2015.1026355

Phan, T. B. N. (2010). Internet use in the teaching English. M.A. Thesis at USSH, Vietnam National University HCM City.

Phan, T. N. T. (2007). The impact of multimedia on students' attitudes and motivation. M.A. Thesis at USSH, Vietnam National University - HCM City.

Pop, A., Tomuletiu, E. A., \& David, D. (2011). EFL speaking communication with asynchronous voice tools for adult students. Procedia-Social and Behavioral Sciences, 15. https://doi.org/10.1016/j.sbspro.2011.03.262 
Prabhu, N. S. (1987). Second language pedagogy. Oxford: Oxford University Press.

Robson, M. (2013). The English Effect - The impact of English, what it's worth to the UK and why it matters to the world. Retrieved on June 14th, 2019 from https://www.britishcouncil.org/sites/default/files/english-effect-report-v2.pdf

Ru-Chu, S. (2010). Blended learning using video-based blogs: Public speaking for English as a second language students. Australasian Journal of Educational Technology, 26(6). https://doi.org/10.14742/ajet.1048

Sachiko, A. (2014). Potential of voice recording tools in language instruction. New York, USA: Columbia University.

Skehan, P. (1996). A Framework for implementation of task-based instructions. Applied Linguistics, 17, 38-62. https://doi.org/10.1093/applin/17.1.38

Skiba, D. (2007). Nursing education 2.0 YouTube. Nursing Education Perspectives, 28(2).

Stillwell, C., Curabba, B., Alexander, K., Kidd, A., Kim, E., Stone, P., \& Wyle, C. (2010). Students transcribing tasks: Noticing fluency, accuracy, and complexity. ELT Journal, 64(4). https://doi.org/10.1093/elt/ccp081

$\mathrm{Su}, \mathrm{T}$. A. M. (2005). The Application of technology in teaching technical English. M.A. Thesis at USSH, Vietnam National University - HCM City.

Sullivan, R. L., \& McIntosh, N. (1996). Delivering effective lectures. JHPIEGO Corporation.

Sun, Y. C. (2009). Voice blog: An exploratory study of language learning. Language Learning \& Technology, $13(2)$.

Sun, Y. (2012). Examining the effectiveness of extensive speaking practice via voice blogs in a foreign language context. CALICO Journal, 29(3).

Sutudenama, E., \& Ramazanzadeh, A. (2011). The effect of oral dialogue journals on Iranian EFL learners' communicative competence. Journal of English Language Teaching and Learning, 53.

Swain, M., \& Lapkin, S. (1995). Problems in output and the cognitive processes they generate: A step towards second language learning. Applied Linguistics, 16(3). https://doi.org/10.1093/applin/16.3.371

Tapscott, D. (1998). Growing up digital: The rise of the net generation. New York: McGraw-Hill.

Tran, T. T. V. (2011). The application of short video clips to improve English learners' oral skills at Binh Duong University Foreign Language Center. M.A. Thesis at USSH, Vietnam National University - HCM City.

Vo, T. H. L. (2006). Computer-assisted language learning: impediments to success. M.A. Thesis at USSH, Vietnam National University - HCM City.

Wallace, M. (1998). Action research for language teachers. The UK: Cambridge University Press.

Williams, M. (2013). What's the best way to teach languages? The Guardian - Teacher Network. Retrieved April 23, 2018, from http://www.theguardian.com/teachernetwork/teacher-blog/2013/may/14/best-wayteach-language-schools

Willis, D. (1996). A framework for task-based learning. London: Longman.

\section{Copyrights}

Copyright for this article is retained by the author, with first publication rights granted to the journal.

This is an open-access article distributed under the terms and conditions of the Creative Commons Attribution license (http://creativecommons.org/licenses/by/4.0/). 